\title{
Teaching Strategies from the Perspective of Learners' Individual Factors
}

\author{
Lili Zhao ${ }^{1}$ \\ ${ }^{1}$ Department of Foreign Language Teaching, Inner Mongolia University for the Nationalities, Tongliao, China \\ Correspondence: Lili Zhao, Department of Foreign Language Teaching, Inner Mongolia University for the \\ Nationalities, Tongliao, China. E-mail: lilingky@163.com
}

Received: October 15, 2015 Accepted: November 9, 2015 Online Published: November 29, 2015

doi:10.5539/ells.v5n4p135 URL: http://dx.doi.org/10.5539/ells.v5n4p135

\begin{abstract}
Individual factors play a significant role in language teaching and learning. However, the phenomenon still exists that cognition and individual differences are separated from each other in college English teaching in China, which attaches too much importance to cognitive side of language learning while neglecting the functions of individual factors. The paper first gives a brief introduction about the present status of language teaching in China. And then the theoretical background of the study is proposed. Afterwards, a detailed analysis is given in this paper about the influences that individual factors bring about on language learning and teaching. Finally, some suggestions are put forward on how to reduce the negative aspects of learners' individual factors to strengthen the positive teaching effects.
\end{abstract}

Keywords: individual factors, humanism, cognition, teaching strategies

\section{Introduction}

In the present educational system of China, English is a basic course and plays an important role. There is a common phenomenon that the learning outcomes of the students differ from each other though they are in the same class, they are taught by the same teacher and they are using the same teaching materials. It has been widely recognized that learners' individual factors have a great impact on the effectiveness of second language learning in addition to the external conditions such as the teaching environment and the teachers. Teachers usually have to deal with students in groups rather than as individuals regardless of the fact that language is learned by individuals not groups. Features of the learner's personality or mind encourage or inhibit the second language learning. Teachers should be aware that learners differ in ways that need careful thought when making decisions about course content and methodology. The study of individual differences is firstly developed from the aspect of psychology and later it is combined with second language learning and acquisition. Cook (2000) discussed the individual factors from the perspectives of learner's motivation, aptitude, learning strategies, age and other personality traits such as cognitive style, personality etc. Since learners' individual factors are vital to second language teaching, more and more attention are drawn to investigate the correlations between learners' individual factors and language teaching.

\section{Theoretical Background}

Humanism has a profound influence on education and FLT. Humanistic approaches, one of the mainstreams of contemporary educational theories and practices, emphasize the importance of the inner world of the learner and place the individual's thoughts, feelings and emotions at the forefront of all human development (Williams \& Burden, 2000, p. 301). Humanism emphasizes the importance of the inner world of the learner and places the individual's thoughts, feelings and emotions at the forefront of all human development. It argues for whole-person development rather than the sole development and employment of cognitive skills. Rogers (1969) identified a number of key elements of the humanistic approach to education. He believed that human beings have a natural potential for learning, however, significant learning will only take place when the subject matter is perceived to be of personal relevance to the learner and when it involves active participation by the learner, i.e. experiential learning. Learning which is self-initiated and which involves feelings as well as cognition is most likely to be lasting and pervasive. Moreover, when there is a perceived threat to the learner's self-image, resistance to teaming is likely to occur. Independence, creativity and self-reliance are most likely to flourish in learning situations where external criticism is kept to a minimum and where self-evaluation is encouraged. 


\section{Individual Factors Affecting Second Language Learning}

\subsection{Intelligence}

Intelligence is a psychological function of human, it is a summation of various psychological factors that successful in understanding objective things and solving the problem, it is a kind of synthetic ability composed by observation, attention, memory, thinking ability, imagination and creativity. In general, the higher the IQ, the better learning results. However, different subjects and the correlation of IQ is not the same. Intelligence impact on second language acquisition has been a great interest to scholars, but so no conclusion has been reached. Some researches have shown that younger learners have small impact of intelligence factors in learning a second language than older. Natural language environment in second language acquisition has little impact on intelligence, but in the formal classroom, with particular emphasis on the form of teaching language, play a greater role in intelligence. Although intelligence is not the decisive factor in second language learning, but teachers or learners should understand the individual factor, pay attention to the different IQ of learners and in learning methods and develop their self-confidence.

\subsection{Personality Factors}

Personality traits are one of the factors that facilitate or inhibit second language learning. The most coherent framework and consistent results have derived from studies on the five-factor model (FFM) or Big Five personality traits, which asserts individual differences in normal behavior should be classified in terms of five orthogonal or independent dimensions, namely Neuroticism, Extraversion, Openness to Experience, Agreeableness, and Conscientiousness. These dimensions reflect individual differences in stable dispositions and preferences that determine each individual's characteristic patterns of thought, emotionality and behavior; they represent aggregated measures of individuals' behavior and can be assessed through self- or other-reports (Chamorro-Premuzic \& Furnham, 2005; Costa \& McCrae, 1992; Digman, 1990; McCrae \& Costa, 1997). The acceptance of the Big Five as the major taxonomy for classifying individual differences in personality has made it easier for differential researchers to explore the correlates or consequential outcomes of personality, including AP, and communicate findings in the same language (Ozer \& Benet-Martinez, 2006; Furnham, Monsen, \& Ahmetoglu, 2009).

Personality traits include a learner's introverted or extroverted character, which is a main concern of the study. The extroversion-introversion distinction refers to one of several dimensions or traits, which together constitute an individual's personality (Eysenck, 1970). Traditionally, the extroverts are thought to be more actively involved in the language activities than the introverts. The extroverts will be more responsive to the input they get, be keener to try producing their own second language utterances and therefore have more chances to build up and test the hypotheses of second language structure. The overall proficiency of the extroverts is considered to be developed more quickly and to a higher level than those introverts. However, the connection is not usually so straightforward. Rossier (1976) found a link between extroversion and oral fluency. The introverts might be expected to prefer academic teaching that emphasizes individual learning and language knowledge; the extroverts audiolingual or communicative teaching that emphasizes group participation and social know-know (Cook, 2000, p. 115).

\subsection{Self-control}

In any culture, the development of self-control is crucial. This ability, which depends on the prefrontal cortex, provides the basis for mental flexibility, social skills and discipline. It predicts success in education, career and marriage. Students succeed in part because they show good self-control. Students' poor self-control in the university increases the risk of poor performance in their academic studies. Self-control is one of the important elements of nonintellectual factors, which has a great impact on a person's life. Those who are successful are mainly the ones with strong self-control. How to cultivate the ability of a student's self-control is of critical importance to language teachers. According to most psychological scientists, self-control can be defined as:

1) The ability to delay gratification, resisting short-term temptations in order to meet long-term goals;

2) The capacity to override an unwanted thought, feeling or impulse;

3) The ability to employ a "cool" cognitive system of behavior rather than a "hot" emotional system;

4) Conscious, effortful regulation of the self by the self.

5) A limited resource capable of being depleted.

\subsection{Self-esteem}

Self-esteem is one of the individual factors that have a great impact on learners' second language learning and 
teaching. It is a widely used concept both in popular language and in psychology. It refers to an individual's sense of his or her value or worth, or the extent to which a person values, approves of, appreciates, prizes, or likes himself or herself (Blascovich \& Tomaka, 1991). Self-esteem, refers to the evaluation which the individual makes and customarily maintains with regard to himself, it expresses an attitude of approval or disapproval, and indicates the extent to which an individual believes himself to be capable, significant, successful and worthy (Coopersmith, 1981). Self-esteem is a kind of important psychological quality of a person and it is an intrinsic power for a person to overcome difficulties, improve oneself and achieve success. It is an essential component for a person to adjust himself and it is a kind of psychological characteristics that reflect the individual's ability to successfully complete a certain activity. A learner with self-esteem is more likely to reach his goals than those less confident ones. While those who lack confidence will let many good chances go because they don't believe they can make it and they can not seize the opportunity. The sense of inferiority might hinder a learner's learning progress.

\section{Teaching Strategies in View of Individual Differences}

\subsection{Teaching Strategies on Intelligence}

The teacher should set up a language environment or provide a picture or some other materials for students. The language environment can be in the waiting room, at the English corner, and in the hospital .The teacher can also arrange the classroom communication as to visiting a friend or watching a football match. According to the teacher's request, the students try to collect materials which can be used in a conversation in class, or give a vivid description of the teaching materials that the teacher assigned. All sorts of activities can be involved in the English lesson. Students can engage in a simple conversation, make up a dialogue or give a vivid expression about some heated topics by means of using their imagination and making a careful design. Research shows that students in such an environment can develop their intellectual potential fully by completing the tasks the teacher assigned. Through a large amount of information input, students are provided with a lot of new knowledge from multiple perspectives. From the point of view of information processing, with more information input and output, students' intelligence are developed and their thinking become more smooth and flexible.

\subsection{Teaching Strategies on Personality Traits}

Teachers are in most cases facing with various kinds of students. First of all, the teacher should recognize the student's individual personality as to develop the classroom atmosphere that is supportive and unthreatening to the students. In such classroom atmosphere, the introverts are more likely to use the second language and more willing to take what they find to be difficult tasks because they feel relaxed and comfortable and do not need to worry about making mistakes or being laughed at. They will benefit as much as possible in the classroom. Secondly, the teacher should prevent the extroverts from doing all the tasks in the classroom and encourage them to pay attention to the feedback of other students and teachers. The teacher needs to remind the extroverts that comprehensible fluency is not sufficient for every context in which they will need to use the language. Thirdly, it is suggested that the teacher should take an overall consideration of the teaching materials and teaching tasks so as to choose appropriate teaching methods to meet the needs of students of different levels.

\subsection{Teaching Strategies on Self-control}

Willpower is one of the important elements of nonintellectual factors, which has a great impact on a person's life. Those who are successful are mainly the ones with strong willpower. How to cultivate a student's willpower is of critical importance to language teachers.

\section{(a) Strengthen the Appropriate Learning Motivation}

People's action is controlled by motivation and motivation is originated from meeting the need of a person. Personal motivation can stimulate tenacious perseverance. Therefore, it is the teacher's duty to help students establish definite learning goals so that they can conduct their learning activities autonomously and purposefully.

(b) Cultivate One's Good Learning Habit

A good learning habit is formed by many efforts and perseverance. The teacher ought to keep records of students' performance in class so that they can help them get rid of bad learning habits. The teacher may give some guidance on students' learning activities and correct their bad and wrong behaviors. The teacher must be strict with the students. Students are asked to finish the tasks on time otherwise they will be punished.

(c) Eliminate the Fear of Difficulty

Students will meet with obstacles when they learn English. Some students will take a positive attitude to overcome difficulties. While other students will behave passively when there is a barrier to language learning 
because they are afraid of failure or being laughed at by others. In this case, first of all, the teacher should understand and respect the students. It is necessary for the students to know that making mistakes is inevitable and there is no need to worry about making mistakes. Students may learn from their mistakes and thus improve their ability of language acquisition. Furthermore, successful learning experience can make students feel more confident. For this reason, the teacher can arrange some easy and simple tasks for the students to perform. Through efforts and hard work, the tasks are finished by the students, and the fulfillment of the tasks is bound to make the students feel confident and proud.

Effective approaches for building self-control combine fun with progressively increasing challenges. Rather than force activities onto an unwilling student, take advantage of his or her individual endencies. When students develop self-control through their own pursuit of happiness, the teacher's instruction weighs less. Find something that students are crazy about but that requires active effort. Whether it's competition activities in language learning or making (but not passively watching) YouTube videos, passionate hobbies build mental staying power that can also be used for their homework.

\subsection{Teaching Strategies on Self-esteem}

a) It is well-known that self-esteem has a profound impact on language learning and language teaching. Recent research has found that by encouraging group interdependence, cooperative activities build greater learner confidence and self-esteem than is likely in a competitive environment, where self-validation is dependent upon a continuing need to demonstrate success (Slavin, 1990). Through cooperative learning, learners tend to interact with each other and they may offer elaborate feedback to their group mates. The students' participation in classroom activities is a good way to develop their personal competence and their immediate personal experience is highlighted during the interaction among students. This, in turn, might result in their personality development and enhancing of self-esteem. Frequent activities in pairs and groups are good for building confidence. Especially for shy learners, they offer a less threatening environment than whole-class work. The more a learner has self-esteem and self-confidence, the more efforts he will make in language learning.

b) Even when the learners know the necessary English and what to do in an activity, they will not participate if they lack confidence. They must not be afraid of speak up in front of the teacher and other learners. It takes time to build up students' confidence, and it comes initially form the example and leadership of the teacher. Most learners will not want to participate if you point out their shortcomings every time they make a mistake. Weaker learners will not risk humiliation if the teacher turns in exasperation to a better learner every time they falter (Davies \& Pearse, 2002).

Therefore, it is up to the teacher to set the tone for all the classroom behavior by means of his own reactions to learner participation, the way he encourage the learners and deal with problems. The teacher needs to spend some time helping the students get familiar with his way of doing things when he starts to teach a new group of students. It is best, first of all, to use simple activities and then move on to more complex ones. By going in for classroom activities, students may gradually find their own way of achieving success and enhance their sense of self-esteem.

\section{Conclusion}

It is of the utmost importance for policy and practice as well as for evaluation and research to have as deep an understanding as possible of the learner group, its social and educational background, its previous language learning experience, and its ethnolinguistic attitudes, motivations, and expectations (Stern, 1992). Although the teacher can't change such learners' individual factors as intelligence, aptitude and personality, he can take some effective measures to teach English in view of these personal factors. Teaching has to recognize the differences between learners. At a gross level this means catering for the factors that a class has in common, say age and type of motivation. At a finer level, the teacher has to cater for the differences between individuals in the class by providing opportunities for each of them to benefit in their own way. For class teaching the aspects in which students are different have to be balanced against those that they share. Therefore, teachers who manage to do with the learners and materials available have to know the differences of learners so as to make their lessons interesting and enjoyable.

\section{References}

Blascovich, J., \& Tomaka, J. (1991). Measures of self-esteem. In J. P. Robinson, P. R. Shaver, \& L. S. Wrightsman (Eds.), Measures of personality and social psychological attitudes (Vol. I). San Diego, CA: Academic Press. http://dx.doi.org/10.1016/B978-0-12-590241-0.50008-3

Carroll, J. (1981). Twenty-five years of research on foreign language aptitude. In K. C. Diller (Ed.), Individual 
Differneces and Universals in Language Learning (pp. 83-118). Rowley, MA: Newbury House.

Cook, V. (2000). Second Language Learning and Language Teaching. Beijing, China: Foreign Language Teaching and Research Press.

Coopersmith, S. (1981). The antecedents of self-esteem. Palo Alto, CA: Consulting Psychologists Press. (Original work published 1967).

Davies, P., \& Pearse, E. (2002). Success in English teaching. Shanghai: Shanghai Foreign Language Education Press.

Dornyei, Z., \& Otto, I. (1998). Motivation in action: a process model of L2 motivation. Working papers in Applied Linguistics, 4, 43-69. London: Thames Valley University.

Gardner, R. C. (1985). Social psychology and second language learning. The role of attitudes and motivation. London: Edward Arnold.

Keller, J. M. (1983). Motivational design of instruction. In C. M. Reigelruth (Ed.), Instructional design theories and models: an overview of their current status (pp. 383-434). Hillsdale, NJ: Lawrence Erlbaum.

Rogers, C. R. (1969). Freedom to Learn. Columbus, Ohio: Charles Merill.

Slavin, R. (1990). Cooperative Learning: Theory, Research and Practice. Englewood Clifs, NJ: Prentice Hall.

Stern, H. H. (1992). Issues and options in language teaching. Shanghai: Shanghai Foreign Language Education Press, 35.

Wedell, M. (1996). Language Teaching \& Learning From Theory To Practice. Beijing, China: Higher Education Press

Williams, M., \& Burden, R. L. (1997). Psychology for Language Teachers. Cambridge: Cambridge University Press.

\section{Copyrights}

Copyright for this article is retained by the author(s), with first publication rights granted to the journal.

This is an open-access article distributed under the terms and conditions of the Creative Commons Attribution license (http://creativecommons.org/licenses/by/3.0/). 